ISSN 1816-6075 (Print), 1818-0523 (Online)

Journal of System and Management Sciences

Vol. 9 (2019) No. 4, pp. 39-49

DOI:10.33168/JSMS.2019.0404

\title{
Entrepreneurship Education and Startups: A Case Study of Less Developed Countries
}

\author{
Yelena Petrenko ${ }^{1}$, Omar Masood ${ }^{2}$, Kiran Javaria ${ }^{3}$, Elena Vechkinzova ${ }^{4}$ \\ ${ }^{1}$ Plekhanov Russian University of Economic, 117997, Moscow, Russia \\ ${ }^{2,3}$ School of Accountancy and Finance, University of Lahore, Islamabad, \\ Pakistan \\ ${ }^{4}$ V. A. Trapeznikov Institute of Control Sciences of Russian Academy of \\ Sciences, Moscow, Russia \\ Ipetrenko_yelena@bk.ru; \\ 2masood_omar@hotmail.com; ${ }^{3}$ kiranmaryam23@gmail.com; ${ }^{4}$ kvin07@list.ru
}

\begin{abstract}
The goal of present study is to explore entrepreneurship educational programs, which helps students in the entrepreneurial startup development. This study is cross sectional and utilizes a data set from three large Asian countries, i.e. Pakistan, India, and Bangladesh. Primary data was collected from three sources (different cities) and study is quantitative in nature. This study's sample size is 837 students and it aims to explore whether entrepreneurship education is a good means to develop entrepreneurial intention and entrepreneurial startup development among them. The study is unique in nature and it will be helpful for policymakers to diminish unemployment through entrepreneurial education design.
\end{abstract}

Keywords: cross sectional study, entrepreneurial education, Asian countries, entrepreneurial startup development, educational programs.

\section{Introduction}

Technological entrepreneurship is one of the important topics highlighted in debates nowadays. Entrepreneurship education has been characterized as an important driver of sustainable socio-economic development. It plays an important role for performing productive activities efficiently and effectively by utilizing commitments, initiatives and innovative efforts (Acs et al., 2008). 
Entrepreneurship is mainly all about innovation and creativity in tasks whereas entrepreneurship education can be defined as a base for polishing that innovativeness (Molle, Djarova 2009).

In developing countries fostering of entrepreneurship obtains especial significance, since it is one of drivers of enhanced development (Tkacova et al., 2018; Baltgailis 2019; Kowo et al., 2019; Girdzijauskaite et al., 2019).

The present study analyses selected universities of such less developed countries as India, Pakistan and Bangladesh. Authors choose universities, which provide entrepreneurship education and orient students towards inseption of startup companies.

The purpose of present study is to identify whether the educational programs have their intended impact. India, Pakistan and Banglades were chosen since they have similar economic and social development level and therefore are comparable.

One of major problems faced by those countries is the high unemployment rate prevailing among graduates passing out each year from the institutions of higher education. The major reason behind the phenomena is the preference of the graduates in the developing countries to become hired employees instead of immersing themselves in a self-employment (e.g. Muller, Korsgaard 2017; Naushad 2018). The aim of present study is to find out whether selected universities of indicated less developed countries sufficiently significantly affect the entrepreneurial startup development.

\section{Literature Review}

Let us recall genesis of entrepreneurship theories. Theory of Planned Behaviour was introduced by Ajzen and Fishbein in 1980 (Ajzen, Fishbein, 1980). The further developed theory of planned behavior is theory of reasoned action presented by Sheppard et al. (1988) who stated that our every action is based on some intention or some reasons. This theory explained that intention of entrepreneurship stemmed from the opinion of desirability and feasibility of a person and this relation is affected by social and cultural context. This model contains some variables of attitude toward behavior and perceived behavior control which is affected by subjective norms (Turker, Selcuk 2009). Later those theories were followed by Theory of Achievement, which was authored by McClelland in 1961 (McClelland 2010). The theory claims that individuals, which need achievement perform better. In contemporary science it is unanimously agreed that entrepreneurial activity through innovations affect economic growth of any country. Therefore, big attention is being paid to entrepreneurs' education both in developed and developing countries 
(Baubonienė et al., 2018; Belas et al., 2018; Bogdanović et al., 2018; Sulphey et al., 2018; Senan 2018; Alajmi, 2019).

Let us look at the entrepreneurial education if our selected countries. Hence, in Pakistan young generation chooses path of business not having formal education in this area (William, Shahid 2016). There is just a bit more than a decade ago higher education institutions started putting empasis on entrepreneurial education (Muhib, Khan 2010). In India entrepreneurial education enrooted five nearly a decade earlier if to compare to Pakistan (Basu 2014). In Bangladesh entrepreneurship educations has been offered by universities already several decades, alas, it seems, that there is no visible impact it on inseption business companies in this country (Azim \& Akbar 2010).

Entrepreneurial education is rather wide and differently understood notion. Let us focus on thee distingueshed approaches towards entrepreneurial education, i.e. Generalized Entrepreneurial Education, Motivational Entrepreneurial Education, and Augmented Entrepreneurial Education.

Generalized Entrepreneurial Education aims to develop usefulness of potential in each individual. This type of learning creates an impression that encourage the students to relate their former principles and theory of knowledge and at the same time this learning develops their practice commitment and provide them experience which lead them to understand their achieved results are successful or failed (Löbler 2006). Motivational Entrepreneurial Education is basically an education which motivate certain individual to choose entrepreneurship as his passion as chose it as his/her career. Therefore, motivational entrepreneurship education is considered as most important driver of launchin of new businesees. Augmented Entrepreneurial Education focuses on self efficacy. According classic literature, self efficacy can be defined as capabilities of an individual for the purpose of organizing and executing the specific course of action in order to tackle with particular situation (Bandura 1995; Li et al. 2017). Similarly, the self system of is mainly the combination of attitudes, abilities and cognitive skills of a particular individual. Additionally, the self system is termed as important because of its reflection on an individuals' perception of any specific situation, as well as behavior of that particular individual in various distinct situations.

In our research we admit that all approached towards entrepreneurial education positivelly affect entrepreneurship developement, which in our case is estimated in number of insepted new companies. As well, we want to find out, which apprach to entrepreneurial education has the most significant result. 


\section{Research Methodology}

Methodology of presented study represents the methods, strategies and approaches used by researchers for study and it also explains the sample, data set collection of study. Research technique used in the study is quantitative in nature and deductive approach was utilized by researcher in which hypothesis were tested for to validate the results. The population of study was universities students of three selected countries India, Pakistan and Bangladesh, and sample taken from the population was three leading universities students of each country. So, the total number of universities was nine. Researchers distributed 100 questionnaires in each university and total sample set was 900. The response rate was $93 \%$, since 837 respondents filled in the questionnaire.

Sample of students selected from Pakistan Universities was from Quaid-iAzam University Islamabad, Fatimah Jinnah University Rawalpindi and Islamic University Islamabad.

Sample of students selected from Indian Universities was from Indian Institute of Technology Delhi (IITD), University of Delhi and University of Calcutta.

Sample of students selected from Bangladesh Universities was from University of Dhaka, Chittagong University and North South University.

The time horizon selected by researchers is cross sectional in which researchers collected data in one point in time in year 2017. Statistical technique used by researcher is Andrew F. Hayes PROCESS technique, which is extension of SPSS software. Researchers used structured questionnaire for analysis. Sampling technique used for the study was non-Probability sampling technique of Convenience sampling. Reliability analysis of study shows that all variables were reliable and accurate. All variables Cronbach's Alpha value was more than $70 \%$, what shows that items were reliable and can be used for further analysis. In questionnaire researchers asked of some demographic/ personal information of students, which is also presented in Table 1.

Table 1 shows that respondents were more male than female as male were $58 \%$ and female customer were $42 \%$ only. More students were from the age group of 21 to 30 and 31 to 40 as their percentages were $37.2 \%$ and $36.9 \%$ respectively, what shows that more students belonged to the age group of 21-30 years. "Program" of study shows that most of the students were doing masters studies in selected universities as their percentage was 43.8\%. At the end researchers used convenient sampling that's why the students who were conveniently available from selected university were chosen as respondent. University of Dhaka from Bangladesh students' response rate is higher than 
other universities (Table 1).

Table 1: Demographic profile of sample

\begin{tabular}{|c|c|c|c|c|c|}
\hline Questions & Options & Frequency & $\begin{array}{c}\text { Percen } \\
\mathbf{t}\end{array}$ & Mean & $\begin{array}{l}\text { Standard } \\
\text { Deviation }\end{array}$ \\
\hline Gender & $\begin{array}{c}\text { Male } \\
\text { Female }\end{array}$ & $\begin{array}{l}485 \\
352\end{array}$ & $\begin{array}{l}57.9 \\
42.0\end{array}$ & 1.753 & 0.431 \\
\hline Age & $\begin{array}{c}\text { Below } 20 \\
21-30 \\
31-40 \\
41 \& \text { above }\end{array}$ & $\begin{array}{l}113 \\
312 \\
309 \\
103\end{array}$ & $\begin{array}{l}13.5 \\
37.2 \\
36.9 \\
12.3\end{array}$ & 1.804 & 0.910 \\
\hline Program & $\begin{array}{l}\text { Under graduate } \\
\text { Master } \\
\text { Doctoral } \\
\text { Diploma }\end{array}$ & $\begin{array}{c}289 \\
367 \\
83 \\
98\end{array}$ & $\begin{array}{c}34.5 \\
43.8 \\
9.9 \\
11.7\end{array}$ & 3.167 & 1.079 \\
\hline $\begin{array}{l}\text { University } \\
\text { (Country) }\end{array}$ & $\begin{array}{c}\text { Quaid-i-Azam } \\
\text { University Islamabad } \\
\text { Fatimah Jinnah } \\
\text { University Rawalpindi } \\
\text { Islamic University } \\
\text { Islamabad } \\
\text { Indian Institute of } \\
\text { Technology Delhi } \\
\text { University of Delhi } \\
\text { University of Calcutta } \\
\text { University of Dhaka } \\
\text { Chittagong University } \\
\text { North South } \\
\text { University }\end{array}$ & $\begin{array}{l}94 \\
95 \\
92 \\
\\
89 \\
93 \\
92 \\
98 \\
93 \\
91\end{array}$ & $\begin{array}{l}11.2 \\
11.3 \\
10.9 \\
10.6 \\
11.1 \\
10.9 \\
11.7 \\
11.1 \\
10.8\end{array}$ & 1.678 & 0.731 \\
\hline
\end{tabular}

Source: developed by theesearcher through SPSS Analysis.

\section{Empirical Analysis}

The empirical analysis of study shows the correlation and regression results of study that what data is suggested about existing variable relationship. The correlation analysis shows that how much variables are depending upon each other while regression analysis shows that one-unit change in independent variable cause how much change in dependent variable. Table 2 provides some useful tests used to validate the hypothesis of present study. 
Table 2: Correlation analysis

\begin{tabular}{|c|c|c|c|c|c|c|}
\hline Variables & Mean & S. D & GEE & MEE & AEE & ETD \\
\hline $\begin{array}{c}\text { Generalized } \\
\text { Entrepreneurial Education }\end{array}$ & 1.906 & 0.639 & 1 & & & \\
\hline $\begin{array}{l}\text { Motivational } \\
\text { Entrepreneurial Education }\end{array}$ & 1.909 & 0.553 & $0.445^{*}$ & 1 & & \\
\hline $\begin{array}{c}\text { Augmented } \\
\text { Entrepreneurial Education }\end{array}$ & 2.005 & 0.673 & $0.378 *$ & $0.365^{*}$ & 1 & \\
\hline $\begin{array}{c}\text { Entrepreneurial start-up } \\
\text { Development }\end{array}$ & 1.929 & 0.611 & $0.577 *$ & $0.526^{*}$ & $0.539 *$ & 1 \\
\hline
\end{tabular}

*Correlation is significant at the 0.01 (99\%) level, ${ }^{* *}$ Correlation is significant at the $0.05(95 \%)$ level, $* * *$ Correlation is significant at the $0.10(90 \%)$ level

Source: Developed by Researcher through SPSS Analysis.

The correlation analysis shows the variable dependency upon each other. In present study the SPSS analysis shows, firstly, the mean and standard deviation of variables. Correlation value should be less than 0.80 ; if it exceeds the limit, variables dependency also increased. In present study correlation between motivational entrepreneurial education and generalized entrepreneurial education is 0.445 , which is moderate correlation between both variables and shows no dependency on each other. The correlation between augmented entrepreneurial education, generalized entrepreneurial education and motivational entrepreneurial education is 0.378 and 0.365 respectively, what shows a weak correlation between variables. And the last one is entrepreneurial startup development correlations with other independent variables is less than 0.6 which shows moderate correlation among variables.

Regression analysis in this study shows how much independent variables (Generalized Entrepreneurial Education, Motivational Entrepreneurial Education and Augmented Entrepreneurial Education) impact dependent variable (Entrepreneurial startup development). In the present study multiple regression analysis was used because there three independent variables. The regression model of study is given below:

\section{Equation:}

Entrepreneurial Startup Development $=\alpha+\beta_{1}$ (Generalized Entrepreneurial Education) $+\beta_{2}$ (Motivational Entrepreneurial Education) $+\beta_{3}$ (Augmented Entrepreneurial Education) +e 
Table 3: Regression analysis

\begin{tabular}{ccccccc}
\hline & $\begin{array}{c}\text { Un- } \\
\text { standardized } \\
\text { Coefficient }\end{array}$ & $\begin{array}{c}\text { Standardized } \\
\text { Coefficient }\end{array}$ & & & & \\
\hline Variables & Beta & Beta & $\mathrm{R}^{\wedge} 2$ & $\mathrm{~T}$ & $\mathrm{Sig}$ & $\mathrm{VIF}$ \\
\hline $\begin{array}{c}\text { Constant } \\
\text { Generalized }\end{array}$ & 0.002 & & & 0.046 & 0.032 & \\
$\begin{array}{c}\text { Entrepreneurial } \\
\text { Education }\end{array}$ & 0.458 & 0.421 & 0.447 & 3.662 & 0.004 & 2.147 \\
$\begin{array}{c}\text { Motivational } \\
\text { Entrepreneurial } \\
\text { Education }\end{array}$ & 0.578 & 0.525 & 0.574 & 4.736 & 0.001 & 3.098 \\
$\begin{array}{c}\text { Augmented } \\
\text { Entrepreneurial } \\
\text { Education }\end{array}$ & 0.541 & 0.491 & 0.544 & 2.150 & 0.000 & 2.445 \\
\hline
\end{tabular}

Source: Developed by researcher through SPSS analysis.

Table 3 shows that Generalized, Motivational and Augmented Entrepreneurial Education have significant impact on Entrepreneurial startup development. Their values are 0.004, 0.001 and 0.000 respectively, which is less than $0.05(\mathrm{P}<0.05)$. $\mathrm{T}$ values of variables are positive which shows that Generalized, Motivational and Augmented Entrepreneurial Education positively affect the entrepreneurial startup development. R square value shows that oneunit changes in independent variable cause how much change in dependent variable. In present study one unit change in Generalized, Motivational and Augmented Entrepreneurial Education cause 0.447, 0.574, 0.544 respectively change in entrepreneurial startup development.

Beta value of variables shows that how strong the relationship between variables is. In presented study Generalized Entrepreneurial Education beta value is 0.458 , which shows that there is 0.458 or 45.8 percent strong relationshipbetween Generalized Entrepreneurial Education and entrepreneurial startup development. Motivational Entrepreneurial Education beta value is 0.578 , which shows that there is 0.578 or 57.8 percent strong relationship between Motivational Entrepreneurial Education and entrepreneurial startup development. Augmented Entrepreneurial Education beta value is 0.541, which shows that there is 0.541 or 54.1 percent strong relationship between Augmented Entrepreneurial Education and entrepreneurial startup development. VIF value should be less than 10. Its value is $2.147,3.098$ and 2.445 , which shows that the data is not collinear. The beta value is positive, what shows the positive impact of Entrepreneurial education in the universities on 
entrepreneurial startup development.

\section{Conclusions}

In a nutshell, present study purpose was to identify effect of different entrepreneurial education programs, which are supposed to foster students' intentions to engage into entrepreneurial activities, which would result then in new business inseption. In presented study data was collected from Asian region; a sample was taken from India Pakistan and Bangladesh universities' students. Sample of study included nine universities; from each country researchers choose three universities on convenience sampling basis. The study is quantitative in nature; researchers utilized Statistical Package of Social Sciences (SPSS) Andrew F. Hayes PROCESS technique for analysis purpose. There are three independent variables which represent three different approaches towards entrepreneurial education. The researchers analyzed impact of each approach on entrepreneurial startup development. Hence, the independent variables are: Generalized Entrepreneurial Education, Motivational Entrepreneurial Education and Augmented Entrepreneurial Education, and dependent variable of study is Entrepreneurial startup development. Results indicated that there is positive and significant relationship between Generalized Entrepreneurial Education, Motivational Entrepreneurial Education, and Augmented Entrepreneurial Education and Entrepreneurial startup development. Furthe, it was found out that Motivational entrepreneurship education has greater impact on dependent variable than other two educational approaches. Researchers recommend that universities should offer new entrepreneurship programs and courses for their students and use motivational technique. Through Motivational entrepreneurship education students are motivated to choose entrepreneurship as way of life. This study will be helpful for policy makers of every country in designing the entrepreneurial education.

Research limitations. It has to be admitted that there might be vague boundries between Generalized Entrepreneurial Education, Motivational Entrepreneurial Education and Augmented Entrepreneurial Education. Besides, study performed with another sample can lead to diffeent results. Despite those research limitations exist, we believe that obtained results are novel, contribute to theory and have practical implications.

\section{References}

Acs, Z.J, Desai, S. \& Hessels, J. (2008). Entrepreneurship, economic development and institutions. Small Business Economics, 31(3), 219-234. 
Ajzen, I. \& Fishbein, M. (1980). Understanding Attitudes and Predicting Social Behaviour. Prentice Hall, Englewood Cliffs. New Jersey.

Alajmi, M. A. (2019). The impact of E-portfolio uses on the development of professional standards and life skills of students in the Faculty of Education at Princess NouraBint Abdul Rahman University. Entrepreneurship and Sustainability Issues, 6(4), 1714-1735. http://doi.org/10.9770/jesi.2019.6.4(12)

Azim, M.T. \& Akbar, M.M. (2010). Entrepreneurship Education in Bangladesh: A Study Based on Program Inputs. South Asian Journal of Management, 17(4).

Baltgailis, J. (2019). The issues of increasing the effectiveness of teaching comparative economics. Insights into Regional Development, 1(3), 190-199. https://doi.org/10.9770/ird. 2019.1.3(1)

Bandura A. (1995). Self-Efficacy in Changing Societies. Cambridge University Press. New York. NY.

Basu, R. (2014). Entrepreneurship Education in India: A Critical Assessment and a Proposed Framework. Technology Innovation Management Review, 4(8), 5-10. http://doi.org/10.22215/timreview/817

Baubonienè, Ž., Hahn, K. H., Puksas, A. \& Malinauskienè, E. (2018). Factors influencing student entrepreneurship intentions: the case of Lithuanian and South Korean universities. Entrepreneurship and Sustainability Issues, 6(2), 854-871. http://doi.org/10.9770/jesi.2018.6.2(26)

Belas, J., Gavurova, B., Cepel, M. \& Kotaskova, A. (2018). Relationship of gender to the position of Slovak University students on the socio-economic determinants of the business environment and the development of entrepreneurship. Entrepreneurship and Sustainability Issues. 6(2), 968-978. http://doi.org/10.9770/jesi.2018.6.2(33)

Bogdanović, M., Vetráková, M., Filip, S. (2018). Dark triad characteristics between economics \& business students in Croatia \& Slovakia: what can be expected from the future employees? Entrepreneurship and Sustainability Issues, 5(4), 967-991. http://doi.org/10.9770/jesi.2018.5.4(19)

Girdzijauskaite, E., Radzeviciene, A. \& Jakubavicius, A. (2019). Impact of international branch campus KPIs on the university competitiveness: FARE method. Insights into Regional Development, 1(2), 171-180. https://doi.org/10.9770/ird.2019.1.2(7)

Kowo, S. A., Adenuga, O. A. O. \& Sabitu, O.O. 2019. The role of SMEs development on poverty alleviation in Nigeria. Insights into Regional Development, 1(3), 214-226. https://doi.org/10.9770/ird.2019.1.3(3) 
Li, J., Qu, J. \& Huang, Q. (2017). Why are some graduate entrepreneurs more innovative than others? The effect of human capital, psychological factor and entrepreneurial rewards on entrepreneurial innovativeness. Entrepreneurship \& Regional Development, 1-23.

McClelland, D.C. (2010). The Achieving Society Paperback - December 10, 2010. Reprint of 1961 edition. https://www.amazon.com/The-AchievingSociety-DavidMcClelland/dp/1891396390/ref=sr11?ie=UTF8\&qid=1386007535\&sr=8$1 \&$ keywords=the+achieving+society

Molle, W. \& Djarova, J. (2009). Enhancing the Effectiveness of Innovation: New Roles for Key Players, Edward Elgar Publishing, Cheltenham.

Muhib, Y. \& Khan, N.A. (2010). The Prospects of Entrepreneurial Education in Pakistan: An Economic Perspective. Journal of Independent Studies and Research-Management. Social Sciences and Economics, 8(2).

Muller, S. \& Korsgaard, S. (2017). Resources and bridging: the role of spatial context in rural entrepreneurship. Entrepreneurship \& Regional Development, 30(1-2) http://doi.org/10.1080/08985626.2017.1402092

Naushad, M. (2018). A study on the antecedents of entrepreneurial intentions among Saudi students. Entrepreneurship and Sustainability Issues, 5(3), 600617. http://doi.org/10.9770/jesi.2018.5.3(14)

Petrenko, Y., Iskakov, N.; Metsyk, O. \& Khassanova, T. (2017). Ecosystem of entrepreneurship: risks related to loss of trust in stability of economic environment in Kazakhstan. Entrepreneurship and Sustainability Issues, 5(1): 105-115.https://doi.org/10.9770/jesi.2017.5.1(8).

Senan, N.A.M. (2018). Developmental review program impact on enhancing the effectiveness of "Teaching and Learning" in accounting program: a case study in a Saudi University. Entrepreneurship and Sustainability Issues, 6(2), 10011017. http://doi.org/10.9770/jesi.2018.6.2(35)

Sheppard, B.H, Hartwick, J. \& Warshaw, P.R. (1988). The theory of reasoned action: a metaanalysis of past research with recommendations for modifications and future research. Journal of Consumer Research, 15(3), 325-343.

Sulphey, M.M, Al Kahtani, N.S., Syed, A.M. (2018). Relationship between admission grades and academic achievement. Entrepreneurship and Sustainability Issues, 5(3), 648-658. http://doi.org/10.9770/jesi.2018.5.3(17)

Shevyakova, A., Petrenko, E., Vechkinzova, Y. \& Koroleva, A. (2019).

Features of the development of female entrepreneurship in Kazakhstan. 33 st 
IBIMA Conference (10-11 April, 2019)/ - Granada, Spai. https://ibima.org/conference/33rd-ibima-conference/

Tkacova, A., Kubak, M., Androniceanu, A., Tvaronavičienė, M. \& Huculova, E. (2018). Financial Literacy of Students in Chosen Universities - Research Platform for Regulatory Processes of Educational System in Slovakia. $E+M$. Economics and Management, 21(1), 175-190.

https://doi.org/10.15240/tul/001/2018-1-012

William, C.C. \& Shahid, M.S. (2016). Informal entrepreneurship and institutional theory: explaining the varying degrees of (in) formalization of entrepreneurs in Pakistan. Entrepreneurship \& Regional Development, 28(1-2), $1-25$. 